\title{
The Economic and Constraints to Shea Tree Conservation among the Shea Value Chain Actors in the North-Central, Nigeria
}

\author{
Garba I.D. ${ }^{1}$ and Muhammad-Lawal A. ${ }^{2}$ \\ ${ }^{1}$ Agricultural Economics Division, Nigerian Institute for Oil-palm Research (NIFOR), \\ P.M.B 1030 Benin City, Edo State, Nigeria \\ ${ }^{2}$ Department of Agricultural Economics and Farm Management, University of Ilorin, \\ P.M.B. 1515, Ilorin, Nigeria \\ 1'ibrahimdanfat@yahoo.com, ${ }^{2}$ Lawaz71@yahoo.com
}

\begin{abstract}
Shea tree species is vulnerable; the density is rapidly declining due to poor conservation. In spite of the need for its preservation, inadequate information on the returns to shea value chain activities and the limiting factors to shea tree conservation among shea value chain actors in the North-central, Nigeria remain worrisome. A three-stage sampling technique was used to draw 387 respondents in North-central Nigeria consisting of 200 and 187 shea value chain actors from Niger and Kwara States respectively. Descriptive statistics, budgeting techniques and Least Significant Difference (LSD) test were used for data analysis. The results revealed that shea butter producers and shea nut collectors produced an average of $126.44 \mathrm{~kg}$ and $634.54 \mathrm{~kg}$ of shea butter and dried shea nut per month, from $337.67 \mathrm{~kg}$ and $1,264.79 \mathrm{~kg}$ of shea resources respectively. Similarly, an average of $1,182.08 \mathrm{~kg}$ of charcoal, $1,377.24 \mathrm{~kg}$ of fuelwood and $248.25 \mathrm{~kg}$ of mortar/pestle and hoe handle (MP\&H) were produced from $2,703.88 \mathrm{~kg}, 1,433.19 \mathrm{~kg}$ and $1,101.23 \mathrm{~kg}$ of inputs per month respectively. The average net returns realized were $\$ 29,607.61, \$ 19,690.45 \$ 22,061.31, \$ 24,521.14$ and $\$ 27,524.15$ per month from shea butter production, shea nut collection, charcoal production, fuelwood gathering and MP\&H making respectively. The returns from the value chain activities showed a significant difference among all the actors ( $p<0.05)$. The major constraints to shea tree conservation for more than $70 \%$ of the shea value chain actors were: scarcity of shea hybrids, long gestation period, low returns, threat from charcoal and fuelwood activities. Furthermore, all the activities in the shea value chain were profitable. And the production of charcoal, fuelwood, MP\&H constitutes threats to shea tree conservation. The study recommends the provision of shea hybrid, enlightenment on shea tree conservation and enforcement of control mechanisms to check wastage.
\end{abstract}

Keywords: Conservation, North-central, Least significant difference, Average, Constraints, Enlightenment

\section{Background to the study}

Shea is a tree widely encountered in dry savannas, forests, and parklands of the Sudan zone of Africa [1]. In Nigeria, shea tree grows widely in Guinea and Sudan savanna belt [2]. And it

Article history:

Received (February 14, 2020), Review Result (March 15, 2020), Accepted (April 17, 2020) 
grows naturally in the wild without the need for irrigation, fertilizer, or pesticides in some of the most challenging inhabited sites. Though, it is found to strive better if cared for. Shea trees when conserved have several biodiversity benefits. It is fire resistant and resilient, the trees provide tree cover in an area that is covered with sparse vegetation, mostly grassland, and highly susceptible to desertification and the trees are a natural carbon sinks and therefore contribute to global climate change mitigation. Apart from the ecological importance of shea tree, it also plays a vital role in improving the standard of living of many households who engage in shea tree activities. Despite its great contribution to the local economies, shea tree remains undomesticated probably because of lack of tradition to plant local tree species. In addition, large shea tree trunks are chopped down to make charcoal, mortars, fuelwood, and for building construction and other purposes. They are reported to produce the best quality charcoal [3]. And are considered more robust, they produce great heat and burn longer than other tree species. The wood of shea tree is as well believed to be strong and conducive for making mortar, pestle, hoe handle and poles.

The shea tree environments have been reported to be degrading steadily resulting in decreasing tree density and vegetation cover [4][5][6]. Fuelwood, charcoal burning and mortar has accounted for the large disappearance of shea trees in most parts of the shea producing areas, because hardwoods like the shea tree are especially popular. This trend suggests the need for the conservation of the specie in farmer's fields for sustainable use and the development of shea value chain. The practice of shea tree conservation that will control the indiscriminate felling and burning of shea tree will have positive impact on the shea value chain. Exploitative activities, like unplanned and intensive land use, uncoordinated expansion of settlement, clearance for farming and wasteful practices in the use of shea trees all have devastating effect on the tree specie and the shea value chain. Reversing this trend to conserve the shea biodiversity and to sustain the shea value chain will depend on the rural community involvement in the planting, facilitating natural regeneration and tending of shea trees on farm to ensure its multiplication.

Shea value chain allows for an assessment of the linkages between and amongst the production activities of various actors and the inter-relationships between diverse actors involved [7][8][9][10][11][12][13][14][15] Value chain describes the full range of value adding activities required to bring a product or service through the different phases of production [16]. Actors are connected along a chain producing, transforming and bringing goods and services to end consumers through a sequenced set of activities [17]. Shea value chain actors are involved in different phases of production, making available shea products to end users. The value chain of shea here includes: shea nuts collectors, shea butter producers, charcoal producers, fuelwood gatherers, as well as mortar/pestle/and hoe handle (MP\&H) makers. Shea nut collectors and shea butter producers are the main value chain actors. Shea collectors or are sometimes referred to as nut traders are the first group along the value chain. They are majorly involved in shea fruits collection and processing to shea kernels. The shea butter producers are the pivot of the industry; they add value to the kernels to produce shea butter which is the most important component of shea tree. Charcoal producers, fuelwood gatherers, mortar/pestle and hoe handle makers transform the shea tree wood logs into end products, and their activities threatened the conservation of shea tree.

Shea tree is threatened, according to International Union for Conservation of Nature (IUCN). They are not established in organized plantations and are poorly represented in protected areas. The tree suffers from indiscriminate harvesting. The pressure on shea tree from individuals as a quick source of income has devastating effect on the major indigenous shea tree specie. Shea tree is important economically; its potentials are not widely 
documented in North-central Nigeria. There is no empirical information on the relative returns to different shea value chain activities. The constraints deterring all efforts to maintain their abundance in the natural environment also need to be investigated. On this basis, the study set to compare the returns to shea value chain activities and highlights the constraints to shea tree conservation among the shea value chain actors. This information will provide genuine basis for government and private interventions in designing shea tree conservation strategies for growth and development of the shea value chain.

\section{Methodology}

\subsection{Study area}

The target population for this study are shea value chain actors in North-central, Nigeria. North-central states consist of Kogi, Niger, Benue, Kwara, Plateau, Nassarawa and the Federal Capital Territory. The region is situated geographically in the middle belt of the country and is rich in natural land features. North-central is vital for shea value chain due to the abundant concentration of shea trees and shea activities [2]. Kwara and Niger State have the largest density of shea tree and shea activities in North-central [18][19].

Kwara State lies within latitudes $7^{\circ} 45^{\prime} \mathrm{N}-9^{\circ} 30^{\prime} \mathrm{N}$ and longitudes $2^{\circ} 30^{\prime} \mathrm{E}-6^{\circ} 23^{\prime} \mathrm{E}$. It covers a total land area of 36, 825 square kilometers or $8 \%$ of the total area of Nigeria [20]. Kwara State consists of sixteen (16) Local Government Areas. The state shares an international boundary with the Republic of Benin [21]. The state is divided into four agricultural zones (Zone A, B, C, and D) by the Kwara State Agricultural Development Project [22]. It is located in the transitional zone between the deciduous woodland of the South and dry savannah of North of Nigeria [23]. Kwara State lies within a region described as tropical climate and are characterized by double rainfall maxima and has tropical wet and dry climate, each lasting for about six months [24][25]. The annual rainfall range from $1000 \mathrm{~mm}$ to $1500 \mathrm{~mm}[25]$ and the temperatures typically range from $33^{\circ} \mathrm{C}$ to $34^{\circ} \mathrm{C}$, while from February to April; the temperature is between $34.6^{\circ} \mathrm{C}$ and $37^{\circ} \mathrm{C}$.

Niger State is divided into three agricultural zones (Zones A, B, C or I, II and III) by the Niger State Agricultural Development Project (ADP), consisting of twenty-five (25) Local Government Areas. Niger State is located between latitudes $8^{\circ} 11^{\prime} \mathrm{N}$ and $11^{\circ} 20^{\prime} \mathrm{N}$ and longitude $4^{\circ} 30^{\prime} \mathrm{E}$ and $7^{\circ} 20^{\prime} \mathrm{E}$. It shares a foreign border with the Republic of Benin in the North-West. The state covers an estimated land mass of 86,000 square kilometers, taking about $10 \%$ of Nigeria's total land mass, of which $85 \%$ is arable land. Niger State experiences distinct dry and wet seasons. The annual rainfall varies from $1,100 \mathrm{~mm}$ in the northern part of the state to $1,600 \mathrm{~mm}$ in the southern parts. The maximum temperature ranges from $23^{\circ} \mathrm{C}$ to $37^{\circ} \mathrm{C}[26]$.

\subsection{Sampling procedure}

Three-stage sampling technique was used in the selection of five (5) shea value chain actors. The first stage involved the purposive selection of two (2) states in North-central Nigeria, specifically Kwara and Niger based on the highest density of shea tree. The second stage involved the purposive selection of five (5) Local Government Areas (LGAs) across the forty-one (41) LGAs in the two states of North-central Nigeria, based on the highest concentration of shea value chain activities. The third stage involved the selection of fourty (40) respondents from each of shea nut collectors and shea butter producers through random sampling technique in each state from the sample frame, as well as forty (40) respondents 
each from fuelwood gatherers, charcoal producers and mortar/pestle/hoe handle makers through snowballing. The study sampled the total of four hundred (400) respondents that were randomly selected from the shea value chain actors from two (2) Local Government Areas in Kwara State and three (3) Local Government Areas in Niger State. The total of three hundred and eighty seven (387) respondents was used for data analysis, consisting of two hundred (200) and one hundred and eighty seven (187) respondents from Niger and Kwara States respectively.

\subsection{Method of data collection and analytical techniques}

The study was based on primary data. Data were elicited using five (5) sets of structured questionnaires that were administered to the main actors along the shea value chain. Both descriptive and inferential statistics was employed to analyze the data from the field survey. Descriptive tools used were: means, cross-tabulations, frequencies and percentages. Other specific tools employed were: budgeting techniques and least significant difference (LSD) test

\subsection{Returns to shea value chain activities}

Net profit $(\Pi)$ was used to assess and compare the returns to different shea value chain actors' activities. Net profit is the Total Revenue minus Total Expenses, thus showing what the enterprises have earned (or lost) for a given period of time. Also called net income or net earnings and this can be specified as:

$$
\begin{array}{r}
\Pi=\sum T R_{i}-\sum T C_{i} \\
\sum T C_{i}=\sum T V C_{i}+\sum T F C_{i}
\end{array}
$$

Where:

$T R=$ total revenue

$\Pi=$ net profit

$T V C=$ total variable cost.

$T F C=$ total fixed cost

$T C=$ total cost of production.

For ease of computation, the straight line method was used in depreciating the capital items that was included in computing fixed cost where applicable. This also involved the spreading of original cost of fixed asset over its useful life. It is necessary to depreciate the initial value of fixed assets in order to guide against over valuation of the cost incurred during production. The formula is given by:

$$
d=\left\{\frac{c-s}{n}\right\}
$$

Where:

$d=$ depreciation $(\#)$

$c=$ purchase value of the asset (cost) (\#)

$S=$ salvage value, which is the value of the asset after its expected year of usage (\#)

$n=$ life span of the asset (years).

Furthermore, in comparing the cost and returns to shea value chain actor's activities, the operational efficiency of all the value chain actors were determined using return on 
investment (ROI) and Operating ratio (OR). Return on investment for each of the value chain actor was calculated using the following formula:

$$
\text { ROI }=\frac{\text { Gain from investment }- \text { Cost }}{\text { Cost }} \times 100 \text { or } \frac{\Pi}{T C}
$$

The higher the coefficient of the ROI the more profit the enterprise. Operating ratio is given as:

$$
\text { Operating ratio }=\frac{\text { Operating exp enses }}{\text { Operating revenues }}
$$

The smaller the ratio the greater the enterprise's ability to generate profit if revenues decreases, is used as a measure of operational efficiency of any enterprise. It measures the business efficient use of capital resources and managerial resources. For further comparison, the least significant difference (LSD) test was used to compare the returns realized from the activities of the shea value actors.

\section{Results and discussion}

This section provides the results obtained from the analysis of data collected for the study.

\subsection{Socioeconomic characteristics of the shea value chain actors}

[Table 1] presents the identified socioeconomic characteristics of shea value chain actors

Table 1. Socioeconomic characteristics of shea value chain actors

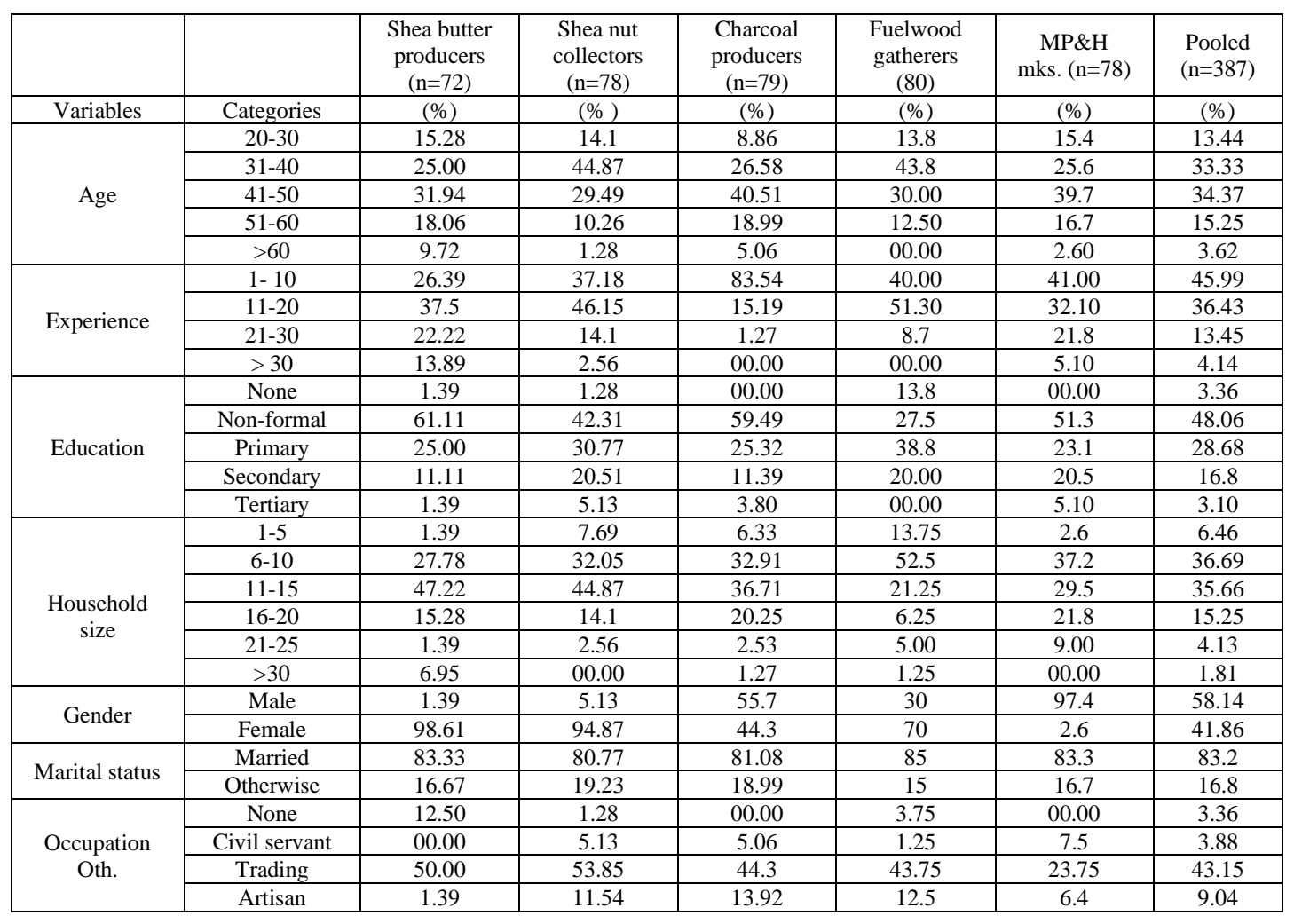


The Economic and Constraints to Shea Tree Conservation among the Shea Value Chain Actors in the Northcentral, Nigeria

\begin{tabular}{|c|c|c|c|c|c|c|c|}
\hline & MoneyLending & 00.00 & 6.41 & 00.00 & 00.00 & 00.00 & 1.29 \\
\hline & Farming & 37.50 & 17.95 & 36.71 & 38.75 & 56.41 & 37.47 \\
\hline \multicolumn{2}{|c|}{ Credit access } & 68.06 & 62.82 & 25.32 & 25.00 & 38.46 & 43.41 \\
\hline \multicolumn{2}{|c|}{ Membership of Association } & 77.78 & 58.98 & 15.19 & 7.50 & 29.49 & 36.95 \\
\hline \multicolumn{2}{|c|}{ Extension service } & 51.94 & 57.69 & 32.91 & 16.25 & 19.23 & 31.52 \\
\hline
\end{tabular}

Field Survey 2017

The activities of the value chain actors are tedious; it requires a physically fit and productive individual within a productive age limit. As shown in Table 1, the modal age for all the shea value chain actors fall within the age range of 31-40 and 41-50 years, which constitute $67.7 \%$ of the respondents. The shea nut collectors (74.36) and fuelwood gatherers (73.8) form the majorities that are within the age range of 31-50. The minimum age was 20 and the maximum (72) years. The mean age of all the respondents was found to be 43 years. This is an indication that majority of the value chain actors are still within the productive age limit during which they can fully and efficiently engage in all forms of productive labour. The modal age bracket and the mean age of the shea value chain actors are noted for their energy, enthusiasm and creativity which have been recognized as being part of any nation's greatest assets. Furthermore, experience in the shea value chain activities could define the productivity and determine the ability of value chain actors to effectively harness the shea resources to their advantages. The estimated mean year of experience of the shea value chain actors was found to be 14 years and the minimum and maximum were 1 and 42 years respectively. The modal year of experience falls within the range of 1-10 and 11-20 years with more than $40 \%$ respondents respectively.

Educational attainment is very vital and is a key to awareness of the danger the shea value chain actors practices may pose to the conservation of shea tree. This is because illiteracy could pose a difficult situation for shea value chain actors to accept innovation that will ensure the sustainable use of shea resources. As shown in Table 3.1, only 16.8 and $28.68 \%$ attained both secondary and primary education. Majority $(48.06 \%)$ of the value chain actors did not have formal education. While less than $4 \%$ had tertiary education. The fact that respondents with tertiary education were not involved in the shea value chain activities is in support of a priori belief that educated ones tend to migrate to the cities in search of white collar jobs while the illiterates remain in the village and live on the forest resources.

The result of the study reported the mean household size of all the shea value chain actors to be 12 people with the minimum of 3 persons and maximum of 42 . The modal household size falls within the household range of 6-10. The majority of the respondents (72.35\%) have $6-15$ household size. The larger household size in the study area is due to the fact that majority of the respondents were married and the family settings is that of the polygamy. This has implication for the fact that household size determines the availability of cheap family labour, since labour intensive activities are mainly carried out by the household. If household size is small, there will be a great need for hired labour by the value chain actors. Large household is regarded as an added labour advantage for increased productivity.

The research work reported $98 \%$ and $95 \%$ women involvement in shea butter production and shea nut collection respectively. Majority (55.7\%) and $97.4 \%$ of the respondents in charcoal production and MP\&H making were men respectively. Fuelwood gathering is dominated by female (70\%). Equally, the analyses revealed that majority $(83.3 \%)$ of all the respondents were married. Marriage is regarded as mark of honour and dignity which is held in high esteem in the study area.

The result further revealed that the shea value chain actors have other sources of income with $43 \%, 37 \%, 1 \%, 9 \%$ and $3 \%$ having their other income sources from trading, farming, money lending, artisan and civil servant respectively. The implication is that income 
generated from the value chain activities is not substantial enough to provide the basic needs of the family, income from other sources could bridge this gap, also help in boosting the productive capital of the shea value chain actors. Credit is viewed as more than giving just raw cash and is a strong tool that is capable of enhancing the productive capacity of the value chain actors [27]. The result shows that only $43.41 \%$ of the value chain actors had access to credit. However, majority of the shea butter producers $(68.06 \%)$ and shea nut collectors $(62.82 \%)$ had access to credit due to the fact that they are more stable and organized in their business activities. The borrowed capital was mainly from friends, relatives and local cooperatives. Fuelwood makers and charcoal producers had less access to credit.

Furthermore, the result revealed that $77.78 \%$ and $58.97 \%$ of shea butter producers and shea nut collectors were members of shea processors union while $29 \%$ of MP\&H makers were members of association. Charcoal and fuelwood producers had the least of record of being members of association (15.19\%) and (7.50) respectively. This implies that shea butter producers and shea collectors are more structured in terms of interacting with their counterparts within and outside their communities. Being a member of association presents a great opportunity of shearing useful information among members and even from the outside through training to improve strategies in production. The result revealed that majority of the shea butter producers (51.94\%) and shea nut collectors (57.69) had higher number of extension contacts. Extension service is relevant to the shea tree conservation in pointing out the menace of deforestation. Progress in any activities could be achieved through extension workers who can transfer the results of scientific research [28].

\subsection{Returns to shea value chain activities}

[Table 2] presents the net returns of the shea value chain actors and the corresponding ROI and OR for further comparison. In addition, [Table 3] shows the result of the LSD test for detailed comparison.

Table 2: Costs and returns to shea value chain activities per month

\begin{tabular}{|c|c|c|c|c|c|c|c|c|c|c|}
\hline \multirow{2}{*}{$\begin{array}{c}\text { Actors } \\
\text { Variables }\end{array}$} & \multicolumn{2}{|c|}{$\begin{array}{l}\text { Shea butter producers }(\mathrm{n}= \\
72)\end{array}$} & \multicolumn{2}{|c|}{$\begin{array}{l}\text { Shea nut collectors } \\
(\mathrm{n}=78)\end{array}$} & \multicolumn{2}{|c|}{ Charcoal producers $(\mathrm{n}=79)$} & \multicolumn{2}{|c|}{$\begin{array}{l}\text { Fuelwood makers } \\
(\mathrm{n}=80)\end{array}$} & \multicolumn{2}{|c|}{$\begin{array}{c}\text { MP\&H makers } \\
(\mathrm{n}=78)\end{array}$} \\
\hline & Qty & Amount $(\mathrm{N})$ & Qty & Amount & Qty & Amount & Qty & Amount & Qty & Amount \\
\hline $\begin{array}{l}\text { Output value } \\
\text { (A) }\end{array}$ & 126.44 & $108,397.31$ & 634.54 & $55,807.69$ & $1,182.08$ & $38,896.20$ & $1,377.24$ & 38,050 & 248.25 & $49,164.09$ \\
\hline $\begin{array}{c}\text { Labour } \\
\text { (Manday) }\end{array}$ & 122.84 & $4,694.44$ & 67.96 & $2,073.06$ & 32.46 & 593.67 & 39.24 & 793.75 & 36.74 & 767.31 \\
\hline Transport & & $4,276.39$ & & $3,258.97$ & & 941.14 & & $2,418.75$ & & $1,912.82$ \\
\hline $\begin{array}{c}\text { Shea fruit } \\
(\mathrm{kg})\end{array}$ & & & $1,264.79^{*}$ & $8,409.30^{*}$ & & & & & & \\
\hline Water (Lt) & $2,016.66^{*}$ & $2,920.83^{*}$ & $581.02^{*}$ & $1,726.28^{*}$ & & & & & & \\
\hline Shea nut $(\mathrm{kg})$ & $377.67^{*}$ & $33,456.89^{*}$ & & & & & & & & \\
\hline Milling & & 4,375 & & & & & & & & \\
\hline $\begin{array}{c}\text { Fuelwood/log } \\
\mathrm{s}(\mathrm{kg})\end{array}$ & $2,099.59^{*}$ & $13,048^{*}$ & $1,689.70^{*}$ & $10,654.78^{*}$ & $2,703.88^{*}$ & $14,344.08^{*}$ & $1,433.19^{*}$ & $9,167.65^{*}$ & $1,101.23^{*}$ & $10,234.78^{*}$ \\
\hline Kerosene (Lt) & 8.17 & 1988.56 & 9.55 & $2,345.78$ & 0.20 & 42.47 & & & & \\
\hline $\begin{array}{l}\text { Comm. } \\
\text { Agents }\end{array}$ & & $2,593.06$ & & 513.82 & & 416.58 & & 641.88 & & $2,461.54$ \\
\hline Total VC (B) & & $67,353.65$ & & $28,981.99$ & & $16,337.94$ & & $13,022.03$ & & $15,376.45$ \\
\hline Rent & & $4,305.56$ & & $2,487.18$ & & 136.71 & & 31.25 & & $3,089.74$ \\
\hline Fees & & $2,489.17$ & & $1,318.59$ & & 49.75 & & 31.25 & & $2,241.34$ \\
\hline $\begin{array}{l}\text { Depreciation } \\
\text { charges }\end{array}$ & & $4,641.32$ & & $3,329.48$ & & 310.49 & & 444.33 & & 932.41 \\
\hline $\operatorname{TFC}(\mathrm{C})=$ & & $11,436.05$ & & $7,135.25$ & & 496.95 & & 506.83 & & $6,263.49$ \\
\hline
\end{tabular}


The Economic and Constraints to Shea Tree Conservation among the Shea Value Chain Actors in the Northcentral, Nigeria

\begin{tabular}{|c|c|c|c|c|c|}
\hline $\begin{array}{c}\mathrm{TC}(\mathrm{D})= \\
(\mathrm{B}+\mathrm{C})\end{array}$ & $78,789.70$ & $36,117.24$ & $16,834.89$ & $13,528.86$ & $21,639.94$ \\
\hline $\begin{array}{l}\text { Net profit (E) } \\
=(\mathrm{A}-\mathrm{D})\end{array}$ & $29,607.61$ & $19,690.45$ & $22,061.31$ & $24,521.14$ & $27,524.15$ \\
\hline $\begin{array}{c}\text { Operating } \\
\text { ratio (D/A) }\end{array}$ & 0.73 & 0.65 & 0.43 & 0.36 & 0.44 \\
\hline ROI (\{E/\}D) & 0.38 & 0.55 & 1.31 & 1.81 & 1.27 \\
\hline
\end{tabular}

The shea butter producer's Variable Cost (VC) constitutes $85 \%$ of the Total Cost (TC) as shown in [Table 2]. The most important and the largest cost component of the shea butter production was the cost of shea nut accounting for about $50 \%$ of the $\mathrm{VC}$. The second highest cost incurred was wood logs cost of $\$ 13,048$ and the cost of water was calculated to be $\$ 2$, 520.83. This implies that shea butter processing consumes a lot of water and wood logs, which is line with the findings of [29] and [19]. Labour and transportation cost $\$ 4,194.44$ and $\$ 4,276.39$ respectively also shows a considerable difference, higher for shea butter producers than any of the value chain actor constituting $12.56 \%$ of the Total Variable Cost (TVC). This is due to the fact that the processing of shea butter requires intensive physical labour [30], sometimes more than what the processors can provide through family labour, likewise shea nuts and shea butter has to be transported to processing center or to the market which attract reasonable cost due to the rural bad roads. Total Fixed Cost (TFC) was calculated to be $\$ 11.436 .05$ higher for shea butter producers than any of the value chain actor; due to the fact that lots of capital items are needed during shea butter production.

Shea nut collector's wood logs cost of $\$ 10,654.78$ and shea fruits cost $\$ 10,654.78$ were the most important and the largest cost components accounting for $65.78 \%$ of the TVC. This is because shea fruits provide the basis for the activities of the collectors; similarly, lot of fuelwood energy is needed for boiling, roasting and frying of nuts. Shea nut collector's labour cost of 2, 073.06 is the highest amongst the shea value chain actors except for shea butter producers. This is because labour is heavily required for de-pulping, boiling, de-husking, drying, roasting and frying of shea fruits. Variable cost shows the most outstanding cost for shea nut collectors accounting for about $80 \%$ of the TC.

In addition, charcoal producer's wood logs cost of N14, 344.08 was the largest, accounting for about $85.2 \%$ of the TVC. Lots of wood logs are heavily consumed during charcoal production. labour cost of N993.67 and transport cost of N941.14 presents the highest after wood logs cost. This is due to the fact that charcoal production demands high labour for cutting tree, chopping in into logs, packing, burning, bagging, sand and leaf piling etc. Wood logs has to be transported to charcoal producing unit if is not produced at the point of logging and charcoal has to be transported to the point of sale. Fixed Cost (FC) constituted only $19.76 \%$ of the TC since charcoal production requires minimal capital items.

Furthermore, fuelwood gatherers largest cost was the cost of wood of $\$ 9,167.65$, followed by cost of transportation $\$ 941.14$ and labour cost of $\$ 793.75$ all constituted $66.7 \%$ of the TVC. This is due to the fact that wood is the primary product for the fuelwood gatherers. Fuelwood on the other hand attract heavy transportation fee because of the heavy nature. And labour is required for cutting, packing and chopping logs into pieces. Variable cost accounted for about $96.3 \%$ of the TC since fewer capital items are needed to venture into the business. Mortar, pestle and hoe handle maker's wood cost was the largest $\$ 10,234.78$ and constituted $66.56 \%$ of TVC. Transportation and labour cost (which include chiseling of woods, cutting, packing, piling, debarking and sand peppering of woods) put together accounted for $17.43 \%$ of the TVC. Variable cost accounted for $71.06 \%$ of the TC.

Furthermore, shea butter producers used an average quantity of $337.67 \mathrm{~kg}$ of shea nut per month at the cost of $\$ 33,456.89$ in the production of shea butter. The quantity of shea butter 
produced was on the average $126.44 \mathrm{~kg}$ at unit price of $857.30 \mathrm{~kg}$ for $1 \mathrm{~kg}$ of shea butter. This makes the total output value of shea butter to be $\$ 108,397.31$. Further analysis revealed the cost of producing $1 \mathrm{~kg}$ of shea butter to be $¥ 623.14$. This makes the total cost of shea butter production to be $\$ 78,789.70$.

Similarly, the quantity of shea fruits use by the collectors was $1,264.79 \mathrm{~kg}$ at a cost of $\# 8$, 409.30. The shea nut produced by the shea collectors was on the average of $634.54 \mathrm{~kg}$ per month at an average price of $\$ 87.95$ for $1 \mathrm{~kg}$ and $\$ 6,191.67$ for a bag. The cost of producing $70.4 \mathrm{~kg}$ of shea nut was calculated to be $\$ 4,007.08$ and $\$ 56.92$ for $1 \mathrm{~kg}$ of shea nut produced. Equally, charcoal value chain actors produced an average of $1,182.08 \mathrm{~kg}$ of charcoal at a unit price of $\$ 32.90$ and $\$ 1,414.7 / \mathrm{bag}$. The cost of producing a bag $(43 \mathrm{~kg})$ of charcoal was estimated to be $\$ 612.40$ at $\$ 14.24$ per $\mathrm{kg}$. Furthermore, fuelwood gatherers produced an average of $1,377.24 \mathrm{~kg}$ and at the average price of $\$ 27.63$ for a unit and $\$ 566.37$ for a bundle of fuelwood. One bundle of fuelwood consists of an average of 20.5 pieces of wood logs equivalent to an estimated value of $45.10 \mathrm{~kg}$ at $2.2 \mathrm{~kg} /$ wood $\log$. The cost of producing 1 bundle of fuelwood was estimated to be $\$ 201.37$. In addition, MP\&H value chain actors produced 1100 pieces of M\&P and 97 units of hoe handles. Equivalent to an average of 15 MP\&Hs put together with an average weight of $248.5 \mathrm{~kg}$ per respondents at an average of $4 \mathrm{~kg}$ per pestle, $10.5 \mathrm{~kg}$ per mortar and $2.05 \mathrm{~kg}$ per hoe handle. The average unit price of mortar and pestle was calculated to be $\$ 2,666.4$ and hoe handle to be $\$ 611.2$.

The result of the net return for all the shea value chain actors showed that the revenue realized exceeded the cost of production. The net profits were $\$ 29,607.61, \$ 19,690.45 \$ 22$, $061.31, \$ 24,521.14$ and $\$ 27,524.15$ for shea butter producers, shea nut collectors, charcoal producers, fuelwood gatherers and MP\&H makers respectively. This positive financial return is an indication that the shea value chain actor's activities were profitable.

Linking the net returns of all the shea value chain actors, it can be deduced that shea butter producers presented the highest return, equally have the lowest business investment opportunities showing the lowest return on investment (ROI) coefficient and the highest operating ratio (OR) of 0.38 and 0.73 respectively. This implies that in every 1 worth of investment in shea butter producing $\$ 0.38$ was realized. Similarly, the producers spend $73 \%$ of their gross income on operating expenses, i.e. $73 \%$ of the sales revenue would be used to cover cost of goods sold. The low investment opportunities and a high OR in shea butter production could be attributed to the high cost incurred during processing and the use of traditional method of shea butter production

which is the most prevalent in the study area. Similarly, fuelwood gatherers present the most efficient business investment opportunity. It shows the highest ROI and the lowest OR of 1.81 and 0.36 respectively. Charcoal production shows the second glaring ROI and OR of 1.31 and $43 \%$ respectively. This is due to the fact that fixed and variable costs incurred were minimal, and equally little capital can start up fuelwood and charcoal production ventures since less capital items are needed in the production process. MP\&H makers and shea nut collectors had 1.27 and $0.55 \mathrm{ROI}$ as well as 0.44 and 0.65 as ORs respectively.

Shea value chain activities are business of choice for the North-central people; it contributes to their household income and provides a safeguard against food shortages and unemployment. The number of people engaged in the shea nut processing and shea $\log$ business is remarkable. Profits are usually concentrated in the hands of a few intermediaries engaged as retailers, transport agents or wholesalers. In addition, this setting is heavily biased against the primary producers who often bear the heaviest workloads. Instead of equitable revenue sharing along the entire value chain, more revenue circulates in a loop between 
middlemen and consumers. Products are either sold in the market, by the road side or at home through wholesaling and retailing to end users. [Figure 1] presents the shea value chain.

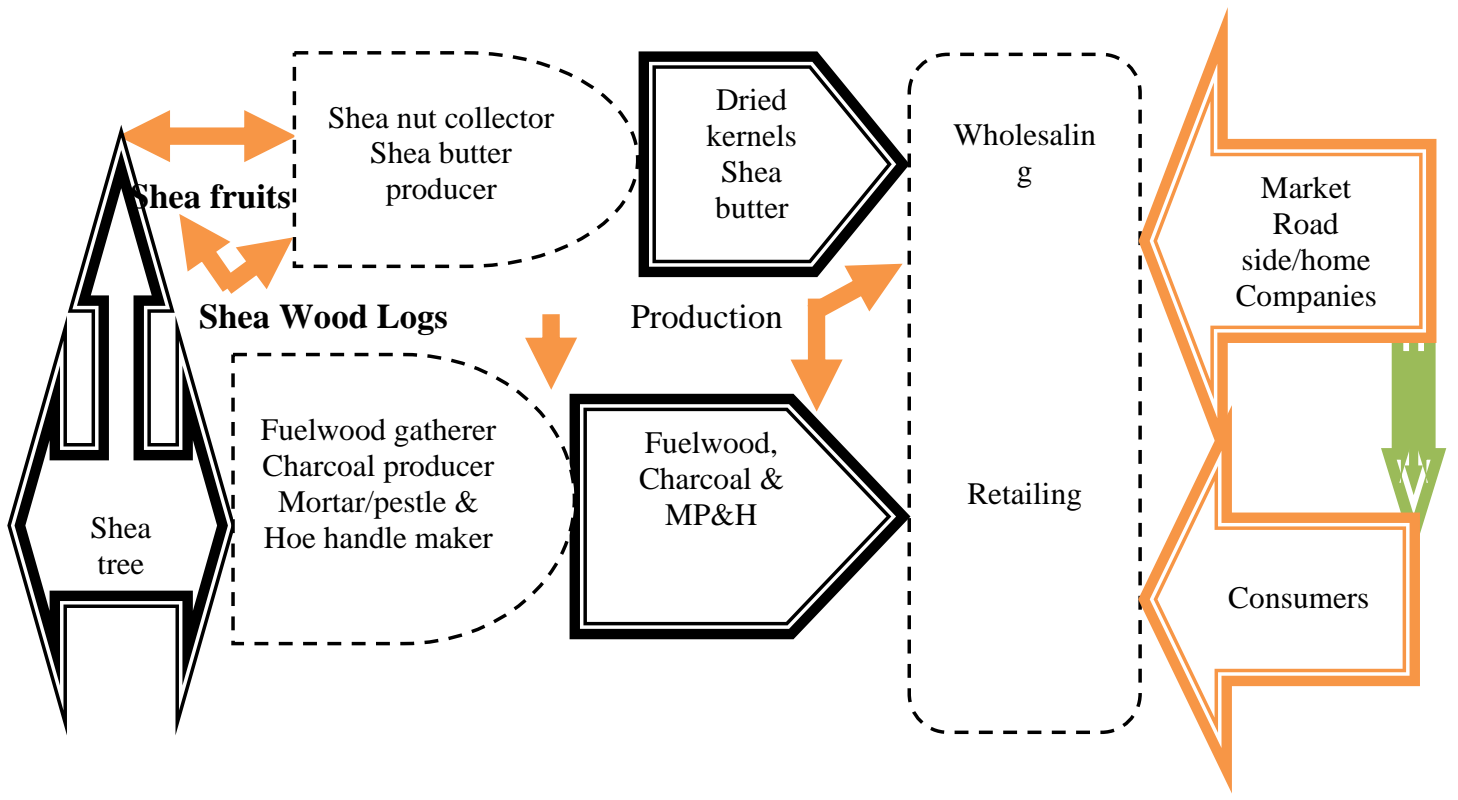

Figure 1. Shea tree value chain

Table 3. Least Significant Difference (LSD) test

\begin{tabular}{|c|c|c|c|c|c|}
\hline \multicolumn{2}{|c|}{ Shea value chain activities per month } \\
\hline & & $\begin{array}{c}\text { Shea } \\
\text { collectors }\end{array}$ & $\begin{array}{c}\text { Charcoal } \\
\text { producers }\end{array}$ & Fuelwood & MP\&H \\
\hline $\begin{array}{c}\text { Shea butter } \\
\text { producers }\end{array}$ & - & 29498.64 & 45872.78 & 37757.23 & 28864.71 \\
\hline & & $(0.001)^{*}$ & $(0.001)^{*}$ & $(0.001)^{*}$ & $(0.001)^{*}$ \\
\hline & & & & & \\
\hline Shea nut collectors & & - & 16374.14 & 8258.59 & -633.94 \\
\hline Charcoal producers & & & $(0.001)^{*}$ & $(0.054) \mathrm{NS}$ & $(0.88) \mathrm{NS}$ \\
\hline & & & - & -8115.54 & -17008.07 \\
\hline Fuelwood gatherers & & & & $(0.057) \mathrm{NS}$ & $(0.001)^{*}$ \\
\hline & & & & - & -8892.53 \\
\hline MP\&H makers & -28864.7 & 633.94 & 17008.07 & 8892.53 & $(0.038)^{*}$ \\
\hline \multicolumn{7}{|l|}{} & $(0.001)^{*}$ & $(0.88) \mathrm{NS}$ & $(0.001)^{*}$ & $(0.038)^{*}$ & - \\
\hline Field Survey 2017 & & & & \\
\hline
\end{tabular}

The LSD test in [Table 3] shows a significant difference between the returns realized by the shea butter producers and other shea value chain actors. Their corresponding P-values were all less than 0.05 significant levels. It is not farfetched considering that shea butter producers recorded the largest output value amongst other shea value chain actors. This implies that shea butter producers earn an additional average monthly income of N29,498.64, $\mathrm{N} 45,872.78$, N37,757.23 and $\mathrm{N} 28,864.71$ than the shea nut collectors, charcoal producers, fuelwood gatherers and MP\&H makers respectively. The analysis also revealed a significant difference in the returns realized by all the value chain actors.

\subsection{Constraints to shea tree conservation}


[Table 4] presents the constraints to shea tree conservation among the shea value chain actors.

Table 4. Constraints to shea tree conservation

\begin{tabular}{|c|c|c|c|c|c|c|c|c|}
\hline $\begin{array}{l}\text { Shea value } \\
\text { chain actors }\end{array}$ & \multicolumn{2}{|c|}{ Not severe } & \multicolumn{2}{|c|}{ M. Severe } & \multicolumn{2}{|c|}{ Severe } & \multicolumn{2}{|c|}{ Extremely Severe } \\
\hline Constraints & Freq. & $\%$ & Freq. & $\%$ & Freq. & $\%$ & Freq. & $\%$ \\
\hline $\begin{array}{l}\text { Low returns } \\
\text { from shea value } \\
\text { chain activities }\end{array}$ & 50 & 12.92 & 183 & 47.29 & 119 & 30.75 & 35 & 9.04 \\
\hline $\begin{array}{l}\text { Long gestation } \\
\text { period before } \\
\text { fruiting }\end{array}$ & 3 & 0.78 & 87 & 22.48 & 117 & 30.23 & 180 & 46.51 \\
\hline $\begin{array}{l}\text { Scarcity of shea } \\
\text { tree } \\
\text { hybrids/shortage } \\
\text { of planting } \\
\text { materials }\end{array}$ & 8 & 2.07 & 74 & 19.12 & 116 & 29.97 & 189 & 48.84 \\
\hline $\begin{array}{c}\text { Lack of } \\
\text { knowledge on } \\
\text { the importance } \\
\text { of shea tree } \\
\text { conservation }\end{array}$ & 24 & 6.20 & 151 & 39.02 & 120 & 31.01 & 92 & 23.77 \\
\hline $\begin{array}{c}\text { Lack of } \\
\text { awareness on } \\
\text { the conservation } \\
\text { strategies of } \\
\text { wild shea } \\
\end{array}$ & 16 & 4.13 & 122 & 31.52 & 168 & 42.12 & 86 & 22.22 \\
\hline $\begin{array}{c}\text { Lack of } \\
\text { ownership of } \\
\text { shea } \\
\text { tree/insecure } \\
\text { tree tenure } \\
\end{array}$ & 23 & 5.94 & 107 & 27.65 & 197 & 50.90 & 60 & 15.51 \\
\hline Land shortage & 81 & 20.93 & 48 & 12.41 & 144 & 37.21 & 114 & 29.46 \\
\hline $\begin{array}{l}\text { Difficulty in } \\
\text { adopting the } \\
\text { shea } \\
\text { conservation } \\
\text { strategies } \\
\end{array}$ & 17 & 4.39 & 115 & 29.72 & 203 & 52.45 & 52 & 13.44 \\
\hline $\begin{array}{c}\text { Bush burning } \\
\text { menace }\end{array}$ & 79 & 20.41 & 83 & 21.45 & 165 & 42.64 & 60 & 15.50 \\
\hline $\begin{array}{l}\text { Inadequate shea } \\
\text { tree around }\end{array}$ & 92 & 23.77 & 119 & 30.75 & 116 & 29.97 & 60 & 15.51 \\
\hline $\begin{array}{c}\text { Land tenure } \\
\text { problem }\end{array}$ & 39 & 10.08 & 121 & 31.27 & 136 & 35.14 & 91 & 23.52 \\
\hline $\begin{array}{l}\text { Threat from } \\
\text { charcoal } \\
\text { producers and } \\
\text { fuelwood } \\
\text { collectors } \\
\end{array}$ & 17 & 4.39 & 63 & 16.28 & 147 & 37.98 & 160 & 41.35 \\
\hline $\begin{array}{l}\text { Indiscriminate } \\
\text { felling of shea } \\
\text { tree during land } \\
\text { clearing \& other } \\
\text { purposes } \\
\end{array}$ & 74 & 19.12 & 65 & 16.80 & 80 & 20.67 & 167 & 43.41 \\
\hline $\begin{array}{l}\text { Pests (termites, } \\
\text { birds etc.) \& }\end{array}$ & 126 & 32.56 & 75 & 19.38 & 96 & 24.81 & 90 & 23.26 \\
\hline
\end{tabular}


The Economic and Constraints to Shea Tree Conservation among the Shea Value Chain Actors in the Northcentral, Nigeria

\begin{tabular}{|c|c|c|c|c|c|c|c|c|}
\hline $\begin{array}{c}\text { diseases } \\
\text { incidence }\end{array}$ & 29 & 10.08 & 159 & 41.09 & 123 & 31.78 & 86 & 17.06 \\
\hline $\begin{array}{c}\text { Weak } \\
\text { conservation } \\
\text { law } \\
\text { enforcement }\end{array}$ & 17 & 4.39 & 155 & 40.05 & 162 & 41.86 & 53 & 13.70 \\
\hline $\begin{array}{c}\text { Inadequate } \\
\text { skill/advisory } \\
\text { services for shea } \\
\text { tree } \\
\text { management }\end{array}$ & 61 & 15.76 & 95 & 24.55 & 156 & 40.31 & 75 & 19.38 \\
\hline $\begin{array}{c}\text { Destruction by } \\
\text { grazing animals }\end{array}$ & 20.67 & 103 & 26.61 & 119 & 30.75 & 85 & 21.97 \\
\hline $\begin{array}{c}\text { Pressure from } \\
\text { collectors as } \\
\text { wild fruits }\end{array}$ & 80 & 13.90 & 103 & 26.61 & 114 & 29.46 & 116 & 29.98 \\
\hline $\begin{array}{c}\text { Pressure from } \\
\text { mortar makers } \\
\& \text { as building } \\
\text { materials }\end{array}$ & 54 & 41.09 & 133 & 34.37 & 64 & 16.54 & 31 & 8.01 \\
\hline $\begin{array}{c}\text { Prolonged } \\
\text { drought }\end{array}$ & 159 & & & & & & \\
\hline Field Survey 2017 & & & & & & & \\
\hline
\end{tabular}

As shown in [Table 4], about $78 \%$ of the shea value chain actors indicated low returns from shea value chain activities as a severe constraint to shea tree conservation. This is in line with the finding of [18] which reported that shea butter and nut have low returns, increasing the market value is required to increase the productive value and stem the destruction of the plant specie. The length of gestation period before fruiting may be a key contributory factor to lack of interest in shea tree conservation. About $76.74 \%$ of the value chain actors viewed it as a severe constraint. The fact is that shea is exceedingly slow growing, reason why most people undermine its conservation.

Scarcity of shea hybrid is a major constraint to its establishment in an organized plantation. About $78 \%$ viewed it as a severe constraint. Further analysis reveals that more than $90 \%$ of the value chain actors are not aware of improved shea seedling or do not have access to it. This implies difficulties in shea tree domestication. Lack of knowledge on the importance of shea tree conservation is a major problem, $70 \%$ viewed it as severe constraint. Lack of awareness of conservation strategies was perceived to be a severe constraint by the majority $(64.34 \%)$. This could be linked to the fact that most shea value chain actors have limited extension contacts with respect to shea tree conservation.

Moreover, $66.41 \%$ viewed insecure tree tenure as severe constraint. Similarly, $57.36 \%$ were severely constrained to the conservation of shea tree due to pressure from shea fruit collectors as wild fruits. Insecure tree tenure is the main challenges of shea tree conservation in the rural settings. Majority see it as a wild fruits with no permanent possessor. Farmers who have shea tree on the farm don't have total control over pickers of fruits and loggers. In addition, availability of land to plant tree crop remains a major problem among the rural dwellers. Further analysis revealed that an individual shea butter producer and shea nut collector owned an average land size of less than 0.5 hectare. The analysis shows that $66.67 \%$ were severely constrained by land shortage. Shea tree plantation establishment requires availability of permanent land with a reasonable size, land fragmentations in the rural areas will hinder any effort of the shea value chain actors to adopt improved shea seedlings.

The study showed that majority of the shea value chain actors $(65.89 \%)$ were severely constrained by the difficulty in the adoption of conservation strategies. This is because shea 
tree ownership is still a major problem, and management practices such as weeding round the shea tree, watering, application of manure, pruning, replanting after logging, preventing bush fire and grazing animals etc. are not easy practices for the conservation of the wild specie. The findings also showed that $58.14 \%$ were severely constrained by the fear of bush fire. The implication is that fire can interfere with the flowering and regeneration of shea which always coincide with the dry season. Severe bush fires generally kill small shea trees; even the fire resistant large shea are reduced to minimum before they could regenerate again. The natural vegetation of shea tree in the north is dominated by grasses that are usually set on fire in the dry season during hunting of wild animals or land clearing. Moreover, $30.75 \%$ and $45.48 \%$ of the shea value chain actors viewed inadequate shea trees within their localities as moderately severe and severe constraint respectively. This could be due to the pressure from loggers. In addition, $66.41 \%$ of the respondents viewed land tenure problem as severe constraint. Continued fragmentations of inherited land have adverse effect on shea tree conservation. Secure tenure of land can significantly motivate farmers to adopt improved shea seedling and or care for the natural growing shea trees.

Equally, $79.33 \%$ viewed menace from charcoal producers and fuelwood gatherers, while $64.08 \%$ viewed indiscriminate felling of shea tree during land clearing and $59.44 \%$ perceived pressure from mortar makers as severe constraints to shea tree conservation respectively. This implies that shea tree vegetation is facing extinction due to the continued exploitation from users. Pests and diseases have negative impact on the management of shea. Caterpillars of Cirina butyrospermii were noted to be adversely defoliating shea butter trees from seedlings to mature trees. However, $32.56 \%$ of shea value chain actors were not severely constrained by the prevalence of pest and diseases while $48.07 \%$ viewed it as severe constraint. This is because shea tree grow by themselves without any management practices, they are however prompt to the attack of pests like birds, termite, human and other diseases.

Furthermore, 41.09 and $48.84 \%$ were constrained by weak conservation law enforcement in a moderately and severe case respectively. While $55.56 \%$ perceived inadequate advisory services for shea tree management as severe constraint. This point to the prevalence of indiscriminate clear-cutting of shea trees, and lack of advisory services on the proper management practices for the preservation of she tree. Similarly, moving grazing animals is a common practice most especially in the northern part of Nigeria, about $59.69 \%$ of the shea value chain actors perceived it as severe constraint. The vegetation is trampled by the large herds of moving and grazing cattle. This most time may result in defoliation of trees, destruction of young shea seedlings and most importantly soil compaction making the environment unfavorable for shea tree regeneration. Grazing animals can greatly interfere with natural regeneration of shea tree species [31]. Equally, prolonged drought is detrimental to the forest resources. Though $41.09 \%$ of the value chain actors were not severely constrained, but $24.55 \%$ viewed it as severe constraint. The northern part of Nigeria where the study was conducted is characterized by long dry season periods, even though shea tree is said to have been able to withstand long dry season, the regeneration of young shea seedlings mainly could be threatened. Finally, the constraints to shea tree conservation and all the findings reported above follow similar trend with the findings of [32][33][34][35].

\section{Conclusion and recommendations}

\subsection{Conclusion}


The shea value chain actors were within the productive age limit, having considerable years of experience in their production activities. The value chain was dominated by men and the activities were profitable with a significant difference in the net returns realized. Fuelwood and charcoal constitute a greater risk for shea tree conservation than the remaining activities along the value chain. The shea value chain actors are faced with a number of constraints that need to be addressed for improvement in the conservation of shea tree in the North-central Nigeria.

\subsection{Recommendations}

In order to conserve the shea resource, the study proffered the following recommendations:

(1) Shea hybrid with a reduced gestation period should be made available. Government and all the stakeholders in the shea value chain should collaborate with the Nigerian Institute for Oil-palm Research (NIFOR) in the area of mass production of improved shea seedlings at a very affordable rate. This will promote the planting of shea tree and curtail the reliance on the natural regeneration.

(2) There should be enlightenment on the values of sustaining the shea tree and the effect of the shea value chain actor's unfavorable practices on the environment. This calls for the need to sensitize the communities on the best shea tree resource conservation practices. Attaining this will sustain the value chain actor's source of income without causing any detrimental effect on the shea tree.

(3) Campaign on regulatory harvest of shea tree for fuelwood and charcoal can ensure its conservation and enhance shea tree density since its development depends on natural regeneration. Bylaws that prohibit the cutting of trees of economic value like shea should be strengthened and enforced.

(4) Addressing issues of land ownership is very paramount. The conservation of the shea tree will only be safeguarded through caring for the existing wild ones or the establishment of shea tree plantation. Government should therefore ease the process of acquisition of land for individuals through the Nigerian Land Use Act to stimulate interest in shea tree conservation.

(5) Although commercialization of shea wood resources provides monetary benefits to the value chain actors, it also threatens the long-term survival of the shea tree. Control mechanisms need to be enforced on loggers to check wastage. Besides, government should promote and enforce shea tree planting. When the system is "take and replace" the conservation of shea tree is guaranteed.

\section{References}

[1] Salle G., Boussim J., Raynal-Roques A. and Brunk, F., Le Karrite, and une richesse potentielle. "Perspectives de recherché pour ameliorer sa production," Bois et forete des tropiques, vol.228, pp.1-23, (1991)

[2] Olaoye J. O., "Enhancement of oil Extraction of Shea butter," Journal of Sustainable Agriculture and the Environment. Dilution/Clarification Protocol (JSAE), vol.3, no.2, pp.353-360, (2001)

[3] Masters E., "The shea resource: Overview of research and development across Africa," pp.13-28, (2006)

[4] Gijsbers H. J. M., Kessler J.J., and Knevel M. K., "Dynamics and natural regeneration of woody species in farmed parklands in the Sahel region (Province of Passore, Burkina Faso)," Forest Ecol. Manage., 64: 1-12, (1994)

[5] De Bie S., Ketner P., Paasse M., and Geerling, C., "Woody plant phenology in West-African savanna," J. Biogeogr., vol.25, pp.883-900, (1998) 
[6] Bado V.B., Bationo A., and Cescas M.P, "Assessment of cowpea and groundnut contributions to soil fertility and succeeding sorghum yields in the Guinean savannah zone of Burkina Faso (West Africa)," Biol. Fertil. Soils, vol.43, pp.171-176, (2006)

[7] Ouédraogo I. "Land Use Dynamics in Bieha District, Sissili Province, Southern Burkina Faso, West Africa," Bull. Afr. Afr. Am. Stud. Program., vol.1, no.2, pp.18-34, (2006)

[8] Kaplinsky R., "Globalisation and unequalization: what can be learned from value chain analysis," Journal of Development Studies, vol.37, no.2, pp.117-146, (2000)

[9] Kaplinsky R., "Competitions policy and the global coffee and cocoa value chains," the United Nations Conference on Trade and Development, (2004)

[10] Dolan C. and Humphrey J., "Governance and trade in fresh vegetables: The impact of UK Super markets on the African horticulture industry," Journal of Development Studies, vol.37, no.2, pp.147-176, (2000)

[11] Schmitz H. and Knorringa, P., "Learning from global buyers," Journal of Development Studies, vol.37, no.2, pp.177-205, (2000)

[12] Fitter R. and Kaplinsky R., "Who gains from product rents as the coffee market becomes more differentiated?" A value chain analysis IDS Bulletin Paper (May), (2001)

[13] Ponte S, "The 'Latte' Revolution? Winners and losers in restructuring of the global coffee marketing chain," CDR Working Paper 01.3, Centre for Development Research Copenhagen, (2001)

[14] Giuliani E., Pietrobelli C., and Rabellotti R., "Up grading in the global value chains: Lessons from Latin American clusters," World Development, vol.33, no.4, pp.549-573, (2005)

[15] Bair J. and Peters E. D., "Global commodity chains and endogenous growth: export dynamism and development in mexico and honduras," World Development, vol.34, no.2, pp.203-221, (2006)

[16] Pietrobelli C. and Saliola F., "Power relationships along the value chain: multinational firms, global buyers and performance of local suppliers," Cambridge Journal of Economics, vol.32, no.6, pp.947-962, (2008)

[17] Webber C. M. and Labaste, P., "Building competitiveness in Africa's agriculture: a guide to value chain concepts and applications," World Bank, retrieved $25^{\text {th }}$ February 2014, (2014)

[18] Riisgaard L. and Ponte S., "Pro-poor value chain development; 25 guiding questions for designing and implementing Agro-industry projects," UNIDO Retrieved 25 ${ }^{\text {th }}$ February 2014, (2014)

[19] Odebiyi J.A, Bada S.O., Awodoyin R.O., Oni P.L., and Omoloyo A.A., "Population structure of Vitelaria paradoxa Gaertn. F. and Parkia biglobosa (Jacq.) Benth. in the agroforestry parklands of Nigerian humid Savanna,” West African Journal of Applied Ecology, no.5, pp.31-39, (2004)

[20] Suleiman M.A.T., "A report on the assessment of potentials for shea nut in selected local government areas in Niger state,” (GTZ-EoPSD) Baseline Conducted in 2008, pp.46, (2008)

[21] Fakayode S.B, Babatunde R.O., and Ajao R., "Productivity of cassava based production systems in the guinea savannah: case study of kawra state Nigeria," America-Eurasian Journal of Scientific Research, vol.3, no.1, pp.33-39, (2008)

[22] Taiwo S., "Rapid assessment of the impact of liberalization and foreign private investment in agriculture for food security and food sovereignty in Nigeria: A case study of Kwara state report of a research conducted as part of the "right to food as human right" project," Trade and Sustainable Development Series no.2, Development Information Network and Heinrich Boll Foundation, (2005)

[23] Kwara Agricultural Development Project (1998-2004): Crop and Area Yield Survey. Annual Report. Kwara State Ministry of Agriculture and Rural Development KWMAR (2004): Planning, Monitoring and Evaluation Department (PME) Annual Report, (2004)

[24] Jimoh H.I., "Erosion tolerance range of land use surfaces: implication on land resource use and management techniques in Ilorin Nigeria," International Journal of Environmental Study, vol,60, pp.446-450, (2003)

[25] Olanrewaju R. M., "Climate and the Growth Cycle of Yam Plant in Guinea Savannah Ecological Zone of Kwara State,” Nigeria. J. of Meteorological and Climate Science, vol.7, pp.43-48, (2009)

[26] Akpenpuun T.D. and Busari, R.A., "Impact of climate on tuber crops yield in Kwara State, Nigeria," American International Journal of Contemporary Research, vol.3, no.10, pp.52-57, (2013) 
The Economic and Constraints to Shea Tree Conservation among the Shea Value Chain Actors in the Northcentral, Nigeria

[27] Sallawu H., Tanko L., Nmadu J.N., and Coker A.A., "Poverty status of farm households in selected local government areas in niger state, Nigeria," Asian Journal of Agricultural Extension, Economics and Sociology, vol.11, no.3, (2016)

[28] Rahji M., "An analysis of the Determinants of Agricultural Credit Approval/Loan Size by Commercial Banks in South-western Nigeria J. of Nigerian Development Studies 200," vol.1, pp.6-25, (2000)

[29] Macadam R.D., "From pushing production inputs to empowering the community: A case study in the transformation of an extension agency," Australian Journal of Experiental Agriculture, vol.40, pp.585-594, (2000)

[30] Niess T., Technologie approprieé pour les femmes des villages. Développement de la presse à karité au Mali. Deutches Zentrum für Entwicklungs technologien, Deutsche Gesellschaft für Technische Zusammenarbeit vieweg \& Sohn, Braunschweig, pp.42, (1988)

[31] Akinsokeji O.A., Tijani S.A., Sanusi M.K., Igene L., and Orifah, M.O., "Perception of modern processing technology by shea butter processors in Kwara State, Nigeria," Journal of Agricultural Extension, vol.21, no.1, pp.1-14, (2017)

[32] Bourliere F., "Ecosystems of the World: Tropical Savannas," Elsevier, Amsterdam, The Netherlands, (1992)

[33] Paul O., Jacob G. A., Clement A. O., and Okullo J. B. L., "On-farm management of vitellaria paradoxa C. F. Gaertn,” In Amuria District, Eastern Uganda International Journal of Forestry Research, vol.2012, article no.768946, pp.8, (2012) DOI :10.1155/2012/768946

[34] Buyinza J. and Okullo J. B. L., "Threats to conservation of vitellaria paradoxa subsp.nilotica (shea butter) tree in nakasongola district, central Uganda," International Research Journal of Environment Sciences, pp.2832, (2015)

[35] McNally D., "Shea butter: A guide to production and marketing," Peace Corps Ghana, Version, vol.1, no.4, (2008) 